This document was prepared in conjunction with work accomplished under Contract No. DE-AC09-96SR18500 with the U. S. Department of Energy.

\title{
DISCLAIMER
}

This report was prepared as an account of work sponsored by an agency of the United States Government. Neither the United States Government nor any agency thereof, nor any of their employees, nor any of their contractors, subcontractors or their employees, makes any warranty, express or implied, or assumes any legal liability or responsibility for the accuracy, completeness, or any third party's use or the results of such use of any information, apparatus, product, or process disclosed, or represents that its use would not infringe privately owned rights. Reference herein to any specific commercial product, process, or service by trade name, trademark, manufacturer, or otherwise, does not necessarily constitute or imply its endorsement, recommendation, or favoring by the United States Government or any agency thereof or its contractors or subcontractors. The views and opinions of authors expressed herein do not necessarily state or reflect those of the United States Government or any agency thereof. 
Keywords: 2H Evaporator

DWPF Recycle

Turbidity

Retention: Permanent

\section{Analysis of Tank 43H Suspended Solids Sample and Sludge Level Meter Testing}

C. J. Martino

Publication date: November 1, 2005

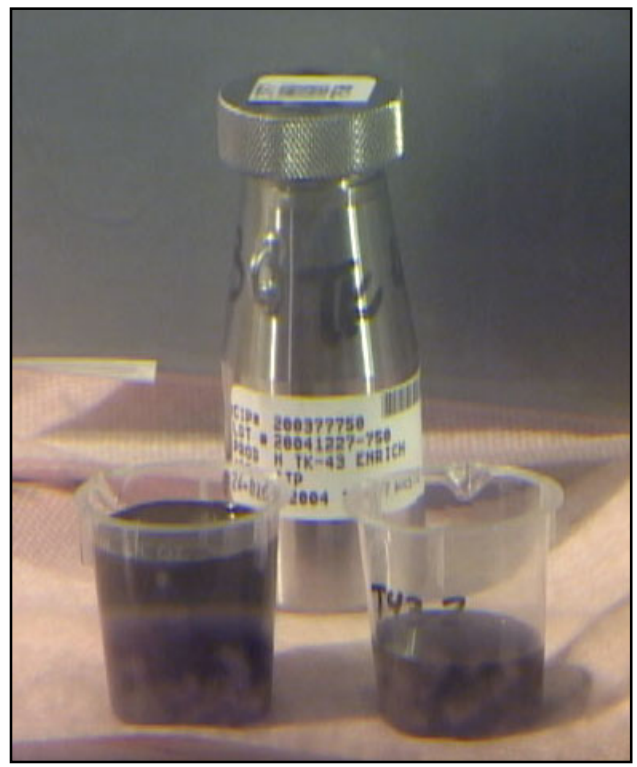

\section{UNCLASSIFIED}

DOES NOT CONTAIN UNCLASSIFIED CONTROLLED NUCLEAR INFORMATION

$$
\text { ADC \& }
$$$$
\text { Reviewing }
$$

Official

Title

Date
SAVANNAH RIVER NATIONAL LABORATORY WESTINGHOUSE SAVANNAH RIVER COMPANY

Savannah River Site, Aiken, SC 29808
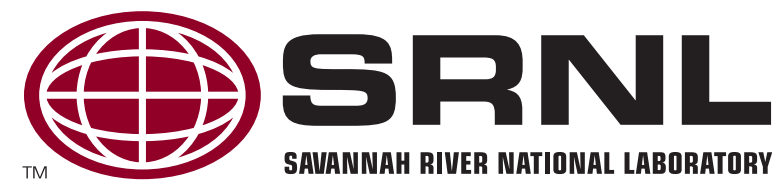


\section{Disclaimer}

This report was prepared by Westinghouse Savannah River Company (WSRC) for the United States Department of Energy under Contract No. DE-AC09-96SR18500 and is an account of work performed under that contract. Neither the United States Department of Energy, nor WSRC, nor any of their employees makes any warranty, expressed or implied, or assumes any legal liability or responsibility for the accuracy, completeness, or usefulness of any information, apparatus, or product or process disclosed herein or represents that its use will not infringe privately owned rights. Reference herein to any specific commercial product, process or service by trademark, name, manufacturer or otherwise does not necessarily constitute or imply endorsement, recommendation, or favoring of same by WSRC or the United States Government or any agency thereof. The views and opinions of the authors expressed herein do not necessarily state or reflect those of the United States Government or any agency thereof.

Printed in the United States of America 


\section{Summary}

The suspended solids in the Tank 43H Enrichment Control Program sample contained 1.85 wt\% uranium with a ${ }^{235} \mathrm{U}$ enrichment of $0.52 \%$. The bulk of the other material in the solids is iron oxide and sodium aluminosilicate (cancrinite).

This report also contains results for the response of the Tank Farm Sludge Level Turbidity Meter to test solutions in the range of $0.008 \mathrm{wt} \%$ to $1.0 \mathrm{wt} \%$ suspended solids. Depending on the suspended solids content, the meter exhibited two types of behaviors. For the more dilute slurries, the resistance readings would rise to a constant value within the first five seconds that the meter was placed in solution. For the more concentrated slurries, very little light reached the detector after it was lowered into the solution and the resistance rose gradually and continually. 
WSRC-TR-2005-00161

Revision 0

\section{Authors:}

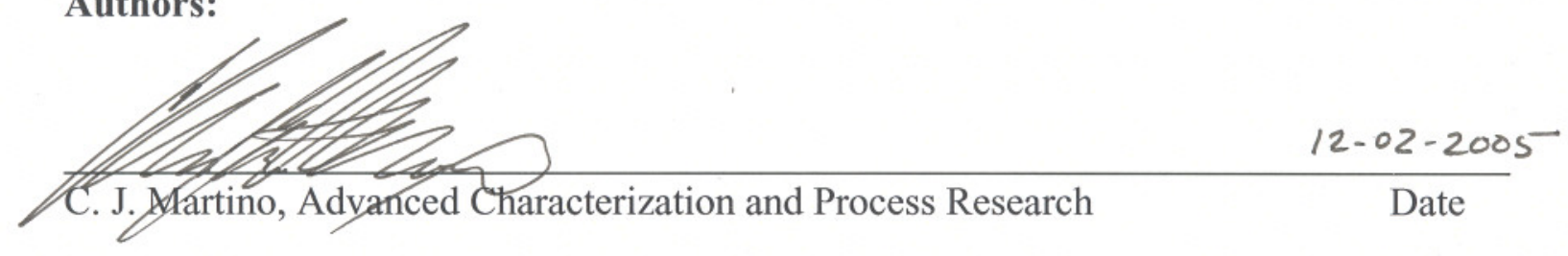

\section{Design Check:}

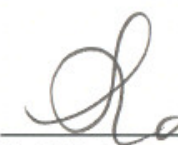

L. N. Oji, Advanced Characterization and Process Research (per Manual E7, Procedure 2.60)

\section{Approvals/Review:}

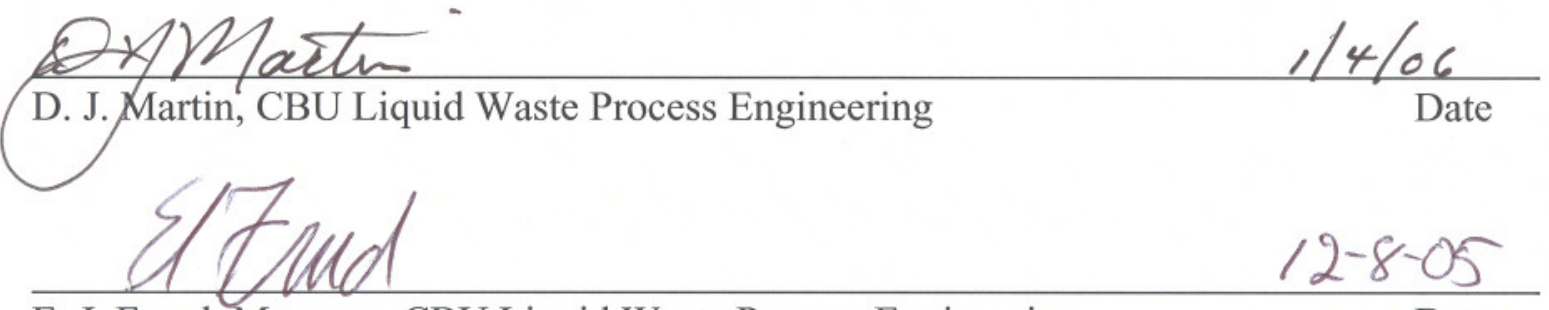

E. J. Freed, Manager, CBU Liquid Waste Process Engineering

Date

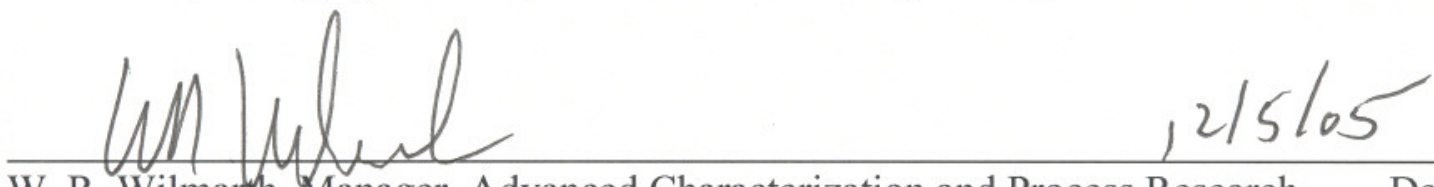

W. R. Wilmarth, Manager, Advanced Characterization and Process Research Date

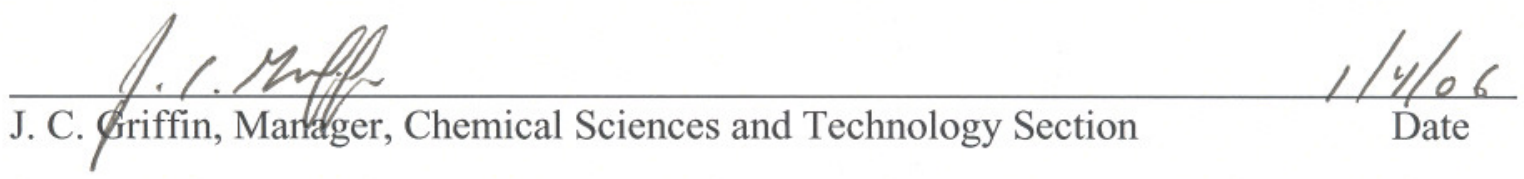




\section{Table of Contents}

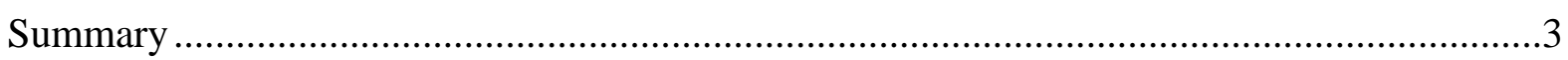

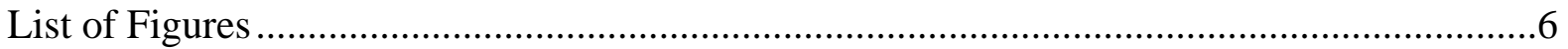

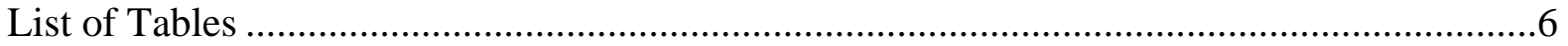

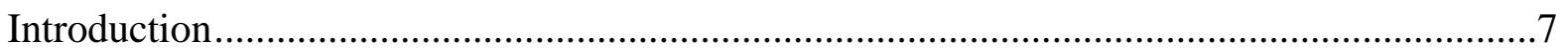

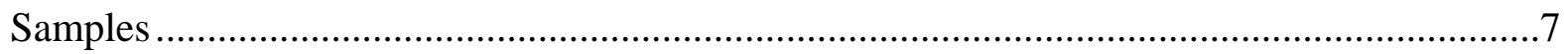

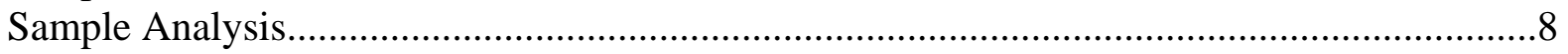

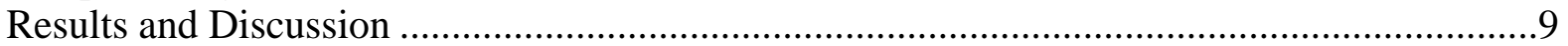

Chemical and Radiological Analyses ......................................................................... 9

Microscopy and Spectroscopy …………………………..................................... 12

Solids Settling Test .......................................................................................................... 16

Sludge Level Turbidity Meter Testing …………………................................................ 17

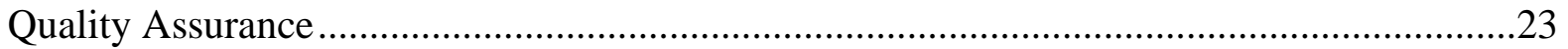

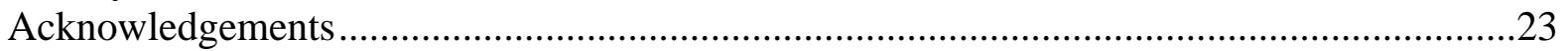

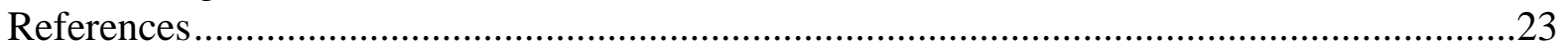


WSRC-TR-2005-00161

Revision 0

\section{List of Figures}

Cover Photo: The Tank 43H sample received at SRNL from C-Lab .................................. 1

Figure 1: The Tank 43H sample received at SRNL from C-Lab...................................... 8

Figure 2: XRD for the unwashed Tank 43H solids.......................................................... 13

Figure 3: SEM micrographs of two areas of the unwashed prepared Tank 43H solids. The top two images are Area 1 and the bottom two images are Area 2. Images on the left are backscattered electron and images on the right are secondary electron images. ............. 14

Figure 4: EDS spectra corresponding to Figure 3....................................................... 15

Figure 5: Solids settling tests of the Tank 43H sample, performed in duplicate: a) day 0 of

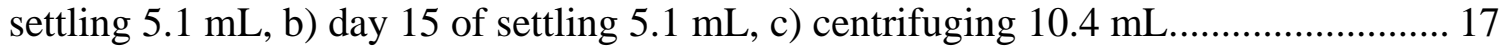

Figure 6: Percent of volume below the supernate/sludge interface for settling $5.1 \mathrm{~mL}$ samples for eight weeks, as compared with centrifuging $10.4 \mathrm{~mL}$ samples. 17

Figure 7: Turbidity of dilute sludge simulants measured with a water-quality turbidity meter.

Figure 8: Photograph of the head of the Sludge Level Turbidity Meter system...................... 20

Figure 9: Transmitted light through $30 \mathrm{~mL}$ aliquots of simulated sludge. ........................... 20 Figure 10: Resistance readings for the Sludge Level Turbidly Meter (with original 2-1/8” gap) with various levels of simulated sludge solids. Values reported for 0.2 and $0.4 \mathrm{wt} \%$ slurries read at $20 \mathrm{sec} .1 \mathrm{wt} \%$ slurry matched $0.4 \mathrm{wt} \%$ slurry results........................... 21

Figure 11: Time-dependent behavior of turbidity meter readings with two different gap sizes (2-1/8" and 1") when used with concentrated sludge slurries 22

\section{List of Tables}

Table 1: ICP-MS results for actinide components in the Tank 43H sample. ...................... 10

Table 2: Radiochemical results for the Tank 43H sample................................................. 10

Table 3: ICP-ES results for metals in the Tank 43H sample........................................... 11

Table 4: Additional notable ICP-MS fission product results......................................... 11

Table 5: Mass balance for solids characterized by warm acid dissolution .......................... 12

Table 6: Summary of Uranium Content of the Tank 43H sample (values in parentheses are standard deviations of two measurements) ................................................................. 12

Table 7: Summary of resistance readings during Sludge Level Turbidity Meter testing...... 21 
WSRC-TR-2005-00161

Revision 0

\section{Introduction}

The atmospheric-pressure evaporator systems at the Savannah River Site (SRS) tank farms remove water from High-Level Waste (HLW) to reduce the volume of waste requiring storage. The current feeds into the $2 \mathrm{H}$-evaporator system originated as the recycle stream from the Defense Waste Processing Facility (DWPF). Tank $43 \mathrm{H}$ is the current feed tank in the $2 \mathrm{H}$-evaporator system. A previous heel of sludge in Tank $43 \mathrm{H}$ contained uranium that was well above natural ${ }^{235} \mathrm{U}$ enrichment (as high as $48 \%{ }^{235} \mathrm{U}$ enrichment). ${ }^{1}$ In the summer of 2001, about 21,000 gallons of depleted uranyl carbonate was added to Tank $43 \mathrm{H}$ in order to deplete the ${ }^{235} \mathrm{U}$ in the supernate so that the supernate could be evaporated with no risk of criticality. ${ }^{2}$ An Enrichment Control Program (ECP) was initiated that required sampling of the $2 \mathrm{H}$-evaporator feed and drop tanks (Tanks $43 \mathrm{H}$ and $38 \mathrm{H}$, respectively) to determine the ${ }^{235} \mathrm{U}$ enrichment of the supernate. ${ }^{3}$ The Tank 43H ECP sample was taken 100 inches from the bottom of the tank in Riser $\mathrm{H}$. This elevation is the same elevation as the entrance to the feed eductor located in Riser R.

In December 2004, a variable depth ECP sample was pulled from Tank 43H and sent to the F/ H Area Analytical Laboratory (C-Lab) for analysis. When solids were unexpectedly discovered in the sample, a portion of the material was shipped to SRNL for further characterization. Analysis of the sample by SRNL began in early January 2005. The analysis of the supernate, washed solids, and wash-water is included in this report. The focus of the solids analysis was on microscopy, analysis for uranium and plutonium isotopics, and metals analysis.

The unexpected discovery of solids in a sample from the 100-inch sampling level of Tank $43 \mathrm{H}$ brought into question the applicability of using the Sludge Level Turbidity Meter to determine dilute slurry ranges. Thus, this report also contains a series of scoping tests examining the response of the Sludge Level Turbidity Meter to intermediate concentrations of solids. Simulated sludge suspended in water was used for these scoping tests.

\section{Samples}

In late December 2004, SRNL received one Tank 43H sample from C-Lab. The sample was labeled H Tk43 Enrich., 24 Dec 2004, and had the C-Lab ID of 200377750. This sample was originally part of the Tank 43H Enrichment Control Program and was pulled on December 24, 2004. This sample was the settled solids portion of a larger (potentially 100 to $200 \mathrm{~mL}$ ) sample sent to C-Lab. The SRNL sample contained $47.5 \mathrm{~mL}(63.588 \mathrm{~g})$ of material with a bulk density of $1.34 \mathrm{~g} / \mathrm{mL}$. Uncertainty on the density is approximated as $\pm 0.03 \mathrm{~g} / \mathrm{mL}$. The bulk material was opaque and dark brown to black in color. Figure 1 shows a picture (taken trough the shielded cells window and color adjusted) of the sample poured into two $30 \mathrm{~mL}$ polypropylene beakers. Subsequent filtration of the bulk sample material showed it to be composed of dark brown to black solids suspended in clear, light yellow liquid. Previous CLab analysis of the liquid portion of this sample revealed that it had a density of $1.3409 \mathrm{~g} / \mathrm{mL}$ and contained $13 \mathrm{mg} / \mathrm{L}$ uranium with $0.51 \%{ }^{235} \mathrm{U}$ enrichment. ${ }^{4}$ 


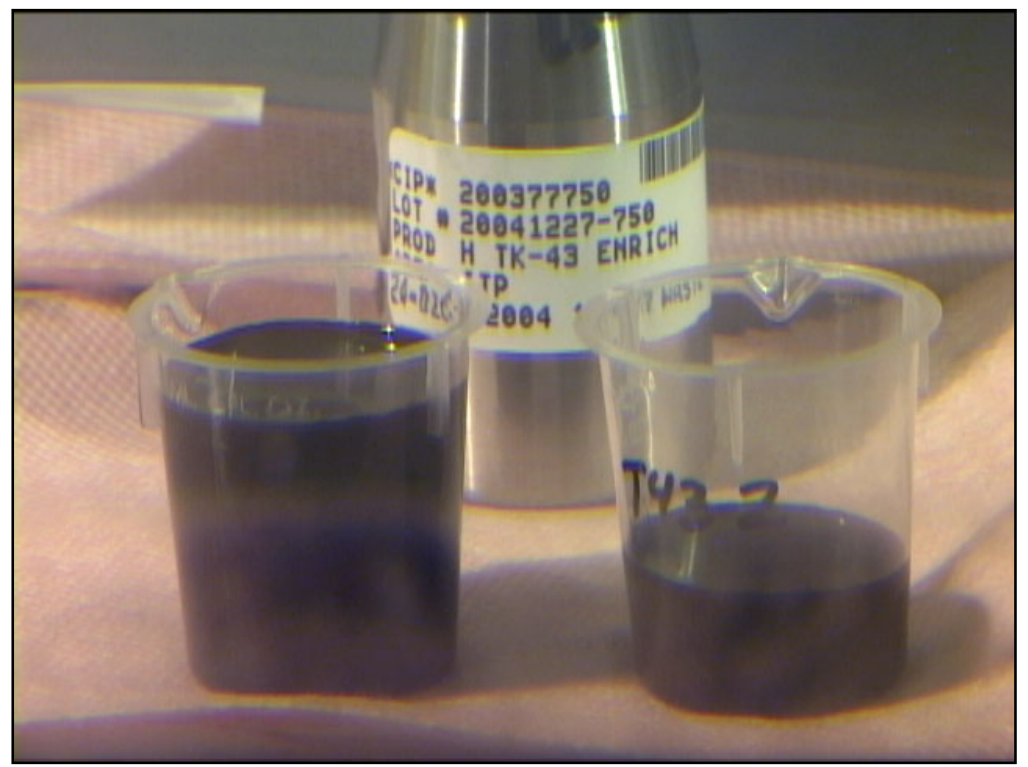

Figure 1: The Tank 43H sample received at SRNL from C-Lab

\section{Sample Analysis}

Sample preparation work was performed in the SRNL shielded cells, cell B10. The sample was agitated, opened, and poured into $30 \mathrm{~mL}$ polypropylene beakers for weight and volume measurement. Approximately $5 \mathrm{~mL}$ of the sample was filtered and small portions of the unwashed filter cake was analyzed by X-ray diffraction (XRD) spectroscopy and by scanning electron microscopy (SEM) with energy dispersive spectroscopy (EDS).

For chemical and radiological analysis, the original material was first separated into its liquid and solid fractions. A total of 29.31 grams of slurry was centrifuged in two $15 \mathrm{~mL}$ polypropylene centrifuge tubes until the solids were compacted to a constant volume. The clarified liquid (henceforth referred to as "supernate”) was decanted from each of the tubes. Subsequently, a total of 21.09 grams of $0.015 \mathrm{M} \mathrm{NaOH}$ solution was added to the solids and the material was mixed. This washing was performed in order to dilute the remaining interstitial fluid without significantly dissolving the solids. The material was again centrifuged to a constant solids level and the clarified dilute liquid (henceforth referred to as "wash”) was decanted. The total of 5.40 grams of wet, washed solids was dried to a constant weight at $90{ }^{\circ} \mathrm{C}$, yielding 2.23 grams of dry solids. Comparing the dry washed solids mass with the original slurry mass, the as-received slurry is estimated to contain $7.6 \mathrm{wt} \%$ solids with a one-sigma standard deviation of $0.1 \%$ resulting from the duplicate measurements.

The supernate and the wash solutions were prepared for analysis by warm acid (nitric) strike. This acidic dissolution method is designed to retain the majority of the compounds in 
solution and provide a method for accurate silicon analysis. The solids were dissolved using a hot nitric/hydrofluoric/hydrochloric acid treatment. This hybrid method was designed to dissolve these potentially high silicon, high iron solids. Some solids remained even after the dissolution process, but these solids were light gray to white and had a much faster settling behavior compared with the original solids. Additional hot concentrated hydrofluoric acid was used to attempt to dissolve the remaining solids. This dissolution was ineffective, so the remaining solids were contacted repeatedly with heated boric acid. There was evidence that the solids were slowly dissolving, but considerable solids remained at the completion of several contacts (comparable to approximately 20\% of the original solid mass). Data for the portion of the solids dissolved to this point are presented in this report as the "solids" composition. The remaining undissolved material was treated with sodium peroxide fusion digestion with nitric acid uptake. This effectively dissolved the residual solid material.

All samples (supernate, wash, solids, and remaining solids) were analyzed by inductively coupled plasma - emission spectroscopy (ICP-ES) for metals, inductively coupled plasma mass spectroscopy (ICP-MS) for actinides and fission products, and by gamma counting for ${ }^{137} \mathrm{Cs}$. Solids and remaining solids samples only were analyzed for plutonium isotopics by radiochemical separation and counting methods. For sample handling and disposal reasons, 0.5 grams of the original slurry was diluted in 10 grams of deionized water and submitted for acid digestion and mercury analysis by cold-vapor atomic absorption (CVAA) spectroscopy.

\section{Results and Discussion}

\section{Chemical and Radiological Analyses}

Table 1, Table 2, and Table 3 contain the ICP-MS results for actinides, the radiochemical counting results for Cs-137 and plutonium isotopes, and the ICP-ES results for metals, respectively. The columns represent the average and the standard deviations of the duplicate separation and analysis of the initially soluble (Supernate) portion of the sample, the water from a single washing of the solids (Wash), and the resulting washed solids (Solids). The results for the solids reported in the tables contains only the portion that dissolved in the heated $\mathrm{HNO}_{3} / \mathrm{HF} / \mathrm{HCl}$ dissolution and the subsequent strikes with $\mathrm{HF}$ and boric acid. It does not contain the results from the subsequent peroxide fusion digestion of the residual undissolved solids. As seen in Table 5, assigning oxides and hydroxides of metals show that about $77 \%$ of the elemental breakdown of the material can be accounted for. The balance of the solids not accounted for are likely aluminum, as discussed in the next paragraph, and anions of sodium salts. Boron content of the solids is not reported due to use of boric acid in the preparation method. Values preceded by " $<$ ” were present at less than the method detection limits, and values preceded by " $<=$ ” are a combination of values from above and below method detection limits.

The peroxide fusion digestion of the solids that did not dissolve initially revealed that the undissolved material was primarily contained aluminum. The warm acid dissolution likely dissolved the original solids and precipitated aluminum-containing solids out of solution due to the large solution concentrations of aluminum and fluoride. Thus, the aluminum value 
reported for the Solids reported in Table 3 and Table 5 are biased low and does not represent the total amount of aluminum in the original solids. Although the undissolved material contained traces of some other metals, most are insignificant when compared with the quantities that did dissolve. The undissolved solids contained too little uranium to determine its enrichment, and the contribution to the enrichment in the original solids is insignificant.

A sample of the slurry was diluted and analyzed for mercury by CVAA after digestion by ADS. The result showed the slurry to contain $1380 \mathrm{mg} / \mathrm{L}$ of mercury, which was likely concentrated in the solids.

The uranium results for the Tank $43 \mathrm{H}$ sample are summarized in Table 6. As with the supernate previously analyzed by C-Lab, the solids had a U-235 enrichment less than that of natural uranium $(0.52 \%)$. The bulk of the uranium contained in the sample was in the solids. The low uranium enrichment of the sample material is contrary to the high enrichment of the original Tank $43 \mathrm{H}$ sludge.

Table 1: ICP-MS results for actinide components in the Tank $43 H$ sample.

\begin{tabular}{|c|c|c|c|c|c|c|}
\hline & \multicolumn{2}{|c|}{ Supernate (mg/L) } & \multicolumn{2}{c|}{ Wash (mg/L) } & \multicolumn{2}{c|}{ Solids (wt \%) } \\
\hline Analyte & Average & St. Dev. & Average & St. Dev. & Average & St. Dev. \\
\hline Mass-232 (Th,U) & -- & -- & -- & -- & $3.43 \mathrm{E}-03$ & $8 \mathrm{E}-05$ \\
\hline Mass-233 $(\mathrm{U})$ & -- & -- & -- & -- & $4.68 \mathrm{E}-05$ & $2.4 \mathrm{E}-06$ \\
\hline Mass-234 $(\mathrm{U})$ & $1.34 \mathrm{E}-02$ & $2.3 \mathrm{E}-03$ & -- & -- & $1.08 \mathrm{E}-03$ & $3 \mathrm{E}-05$ \\
\hline Mass-235 $(\mathrm{U})$ & $7.55 \mathrm{E}-02$ & $4.1 \mathrm{E}-03$ & $3.81 \mathrm{E}-02$ & $1.01 \mathrm{E}-02$ & $9.59 \mathrm{E}-03$ & $1.6 \mathrm{E}-04$ \\
\hline Mass-236 $(\mathrm{U})$ & $1.07 \mathrm{E}-02$ & $3.9 \mathrm{E}-03$ & $6.55 \mathrm{E}-03$ & $4.00 \mathrm{E}-03$ & $1.63 \mathrm{E}-03$ & $6 \mathrm{E}-05$ \\
\hline Mass-237 $(\mathrm{Np})$ & $1.26 \mathrm{E}-02$ & $8 \mathrm{E}-04$ & -- & -- & $2.09 \mathrm{E}-03$ & $6 \mathrm{E}-05$ \\
\hline Mass-238 $(\mathrm{U}, \mathrm{Pu})$ & $1.34 \mathrm{E}+01$ & $2 \mathrm{E}-01$ & $6.48 \mathrm{E}+00$ & $5.1 \mathrm{E}-01$ & $1.85 \mathrm{E}+00$ & $6 \mathrm{E}-02$ \\
\hline Mass-239 $(\mathrm{Pu})$ & $2.10 \mathrm{E}-02$ & $3 \mathrm{E}-03$ & -- & -- & $2.09 \mathrm{E}-03$ & $5 \mathrm{E}-05$ \\
\hline Mass-240 $(\mathrm{Pu})$ & -- & -- & -- & -- & $3.61 \mathrm{E}-04$ & $4 \mathrm{E}-06$ \\
\hline Mass-241 $(\mathrm{Am}, \mathrm{Pu})$ & -- & -- & -- & -- & $2.43 \mathrm{E}-04$ & $9 \mathrm{E}-06$ \\
\hline Mass-242 $(\mathrm{Pu})$ & -- & -- & -- & -- & $5.01 \mathrm{E}-04$ & $1.7 \mathrm{E}-05$ \\
\hline Mass-243 $(\mathrm{Am}, \mathrm{Cm})$ & -- & -- & -- & -- & $4.95 \mathrm{E}-05$ & $1.72 \mathrm{E}-05$ \\
\hline Mass-244 $(\mathrm{Pu}, \mathrm{Cm})$ & -- & -- & -- & -- & $2.00 \mathrm{E}-05$ & $4.4 \mathrm{E}-06$ \\
\hline
\end{tabular}

Table 2: Radiochemical results for the Tank $43 H$ sample.

\begin{tabular}{|c|c|c|c|c|c|c|}
\hline & \multicolumn{2}{|c|}{ Supernate (pCi/mL) } & \multicolumn{2}{c|}{ Wash $(\mathrm{pCi} / \mathrm{mL})$} & \multicolumn{2}{c|}{ Solids (pCi/g) } \\
\hline Analyte & Average & St. Dev. & Average & St. Dev. & Average & St. Dev. \\
\hline Cs-137 & $1.39 \mathrm{E}+08$ & $6 \mathrm{E}+06$ & $2.85 \mathrm{E}+07$ & $1.8 \mathrm{E}+06$ & $1.99 \mathrm{E}+08$ & $9 \mathrm{E}+06$ \\
\hline Pu-238 & not tested & -- & not tested & -- & $2.08 \mathrm{E}+08$ & $8 \mathrm{E}+06$ \\
\hline Pu-239/240 & not tested & -- & not tested & -- & $1.87 \mathrm{E}+06$ & $6 \mathrm{E}+03$ \\
\hline $\mathrm{Pu}-241$ & not tested & -- & not tested & -- & $2.73 \mathrm{E}+07$ & $1.3 \mathrm{E}+06$ \\
\hline
\end{tabular}


Table 3: ICP-ES results for metals in the Tank $43 \mathrm{H}$ sample.

\begin{tabular}{|c|c|c|c|c|c|c|}
\hline & \multicolumn{2}{|c|}{ Supernate (mg/L) } & \multicolumn{2}{|c|}{ Wash (mg/L) } & \multicolumn{2}{|c|}{ Solids (wt \%) } \\
\hline Analyte & Average & St. Dev. & Average & St. Dev. & Average & St. Dev. \\
\hline $\mathrm{Ag}$ & $<2.10 \mathrm{E}+00$ & -- & $<2.12 \mathrm{E}+00$ & -- & $7.96 \mathrm{E}-03$ & 2.3E-04 \\
\hline $\mathrm{Al}$ & $3.64 \mathrm{E}+03$ & $5 \mathrm{E}+01$ & $6.15 \mathrm{E}+02$ & $3.5 \mathrm{E}+01$ & $2.56 \mathrm{E}+00$ & 2.5E-01 \\
\hline $\mathrm{B}$ & $2.07 \mathrm{E}+02$ & $3 \mathrm{E}+00$ & $2.64 \mathrm{E}+01$ & $4.3 \mathrm{E}+00$ & -- & - \\
\hline $\mathrm{Ba}$ & $<1.68 \mathrm{E}+00$ & -- & $<1.70 \mathrm{E}+00$ & -- & $1.51 \mathrm{E}-02$ & 1.2E-03 \\
\hline $\mathrm{Ca}$ & $<1.90 \mathrm{E}+00$ & -- & $<1.91 \mathrm{E}+00$ & - & $1.69 \mathrm{E}+00$ & 6E-02 \\
\hline $\mathrm{Cd}$ & $<2.71 \mathrm{E}+00$ & -- & $<2.74 \mathrm{E}+00$ & - & $1.54 \mathrm{E}-02$ & 5E-04 \\
\hline $\mathrm{Ce}$ & $<2.84 \mathrm{E}+01$ & -- & $<2.87 \mathrm{E}+01$ & -- & $3.28 \mathrm{E}-02$ & 2.0E-03 \\
\hline $\mathrm{Cr}$ & $1.64 \mathrm{E}+02$ & $5 \mathrm{E}+00$ & $2.58 \mathrm{E}+01$ & $2.1 \mathrm{E}+00$ & 1.99E-01 & 7E-04 \\
\hline $\mathrm{Cu}$ & $2.97 \mathrm{E}+00$ & $1.9 \mathrm{E}-01$ & $<2.12 \mathrm{E}+00$ & -- & 5.63E-02 & 3E-04 \\
\hline $\mathrm{Fe}$ & $8.66 \mathrm{E}+00$ & $1.5 \mathrm{E}-01$ & $<=4.23 \mathrm{E}+00$ & - & $2.57 \mathrm{E}+01$ & 7E-02 \\
\hline $\mathrm{Gd}$ & $<3.58 \mathrm{E}+00$ & -- & $<3.61 \mathrm{E}+00$ & -- & 4.96E-02 & 2.8E-03 \\
\hline $\mathrm{K}$ & $9.65 \mathrm{E}+02$ & $5.9 \mathrm{E}+01$ & $<1.65 \mathrm{E}+02$ & -- & $<1.40 \mathrm{E}-01$ & -- \\
\hline $\mathrm{La}$ & $<1.09 \mathrm{E}+01$ & -- & $<1.10 \mathrm{E}+01$ & - & $9.78 \mathrm{E}-03$ & 5.9E-04 \\
\hline $\mathrm{Li}$ & $3.71 \mathrm{E}+01$ & 4E-01 & $<=1.09 \mathrm{E}+01$ & - & $1.13 \mathrm{E}-01$ & $0 \mathrm{E}+00$ \\
\hline $\mathrm{Mg}$ & $<8.42 \mathrm{E}-01$ & -- & $<8.49 \mathrm{E}-01$ & -- & $1.48 \mathrm{E}-01$ & 9E-03 \\
\hline $\mathrm{Mn}$ & $<4.21 \mathrm{E}-01$ & -- & $<4.25 \mathrm{E}-01$ & - & $1.85 \mathrm{E}+00$ & 7E-03 \\
\hline Mo & $<2.80 \mathrm{E}+01$ & -- & $<2.83 \mathrm{E}+01$ & -- & 7.17E-02 & 2.3E-03 \\
\hline $\mathrm{Na}$ & $1.89 \mathrm{E}+05$ & $2 \mathrm{E}+03$ & $3.16 \mathrm{E}+04$ & $2.2 \mathrm{E}+03$ & $8.78 \mathrm{E}+00$ & 7.4E-01 \\
\hline $\mathrm{Ni}$ & $<1.96 \mathrm{E}+01$ & -- & $<1.98 \mathrm{E}+01$ & -- & 2.15E-01 & 7E-04 \\
\hline $\mathrm{P}$ & $3.85 \mathrm{E}+02$ & $1.8 \mathrm{E}+01$ & $<=5.76 \mathrm{E}+01$ & - & $1.41 \mathrm{E}-01$ & $8 \mathrm{E}-03$ \\
\hline $\mathrm{Pb}$ & $<1.01 \mathrm{E}+02$ & -- & $<1.02 \mathrm{E}+02$ & -- & $<8.58 \mathrm{E}-02$ & -- \\
\hline $\mathrm{S}$ & $1.38 \mathrm{E}+03$ & $6 \mathrm{E}+01$ & $1.95 \mathrm{E}+02$ & $1.9 \mathrm{E}+01$ & 8.38E-02 & 5.7E-03 \\
\hline $\mathrm{Sb}$ & $2.06 \mathrm{E}+01$ & $1.6 \mathrm{E}+00$ & $<1.06 \mathrm{E}+01$ & -- & 9.52E-02 & 8E-04 \\
\hline $\mathrm{Si}$ & $<1.02 \mathrm{E}+02$ & -- & $<1.03 \mathrm{E}+02$ & -- & $3.51 \mathrm{E}+00$ & $6 \mathrm{E}-02$ \\
\hline Sn & $<6.31 \mathrm{E}+01$ & -- & $<6.37 \mathrm{E}+01$ & - & $2.27 \mathrm{E}-01$ & 9E-03 \\
\hline $\mathrm{Sr}$ & $<2.10 \mathrm{E}+00$ & -- & $<2.12 \mathrm{E}+00$ & -- & $3.26 \mathrm{E}-01$ & 1.3E-02 \\
\hline $\mathrm{Ti}$ & $<6.31 \mathrm{E}-01$ & -- & $<6.37 \mathrm{E}-01$ & -- & 2.97E-02 & 1.6E-03 \\
\hline $\mathrm{V}$ & $<4.21 \mathrm{E}+00$ & -- & $<4.25 \mathrm{E}+00$ & -- & $7.41 \mathrm{E}-03$ & 4.1E-04 \\
\hline $\mathrm{Zn}$ & $2.88 \mathrm{E}+01$ & 2E-01 & $<3.19 \mathrm{E}+00$ & -- & 1.59E-01 & 7E-04 \\
\hline $\mathrm{Zr}$ & $<1.68 \mathrm{E}+00$ & -- & $<1.70 \mathrm{E}+00$ & -- & $4.00 \mathrm{E}-03$ & $3.6 \mathrm{E}-04$ \\
\hline
\end{tabular}

Table 4: Additional notable ICP-MS fission product results

\begin{tabular}{|c|c|c|c|c|c|c|}
\hline & \multicolumn{2}{|c|}{ Supernate (mg/L) } & \multicolumn{2}{c|}{ Wash (mg/L) } & \multicolumn{2}{c|}{ Solids (wt \%) } \\
\hline Analyte & Average & St. Dev. & Average & St. Dev. & Average & St. Dev. \\
\hline Mass-59 $(\mathrm{Co})$ & -- & -- & -- & -- & $6.89 \mathrm{E}-03$ & $2.3 \mathrm{E}-04$ \\
\hline Mass-88 $(\mathrm{Sr})$ & $7.80 \mathrm{E}-02$ & $4.4 \mathrm{E}-03$ & $6.95 \mathrm{E}-02$ & $6.47 \mathrm{E}-03$ & $4.10 \mathrm{E}-03$ & $1.02 \mathrm{E}-03$ \\
\hline Mass-99 $(\mathrm{Tc})$ & $2.95 \mathrm{E}+00$ & $9 \mathrm{E}-02$ & $4.69 \mathrm{E}-01$ & $1.04 \mathrm{E}-02$ & $9.14 \mathrm{E}-04$ & $7.5 \mathrm{E}-05$ \\
\hline Mass-103 (Rh) & -- & -- & -- & -- & $4.58 \mathrm{E}-04$ & $5 \mathrm{E}-06$ \\
\hline Mass-127 (I) & $1.45 \mathrm{E}+00$ & $6 \mathrm{E}-02$ & -- & -- & $5.18 \mathrm{E}-03$ & $6.5 \mathrm{E}-04$ \\
\hline
\end{tabular}


WSRC-TR-2005-00161

Revision 0

Table 5: Mass balance for solids characterized by warm acid dissolution

\begin{tabular}{|c|c|}
\hline Component & wt \% \\
\hline $\mathrm{AlO}_{3}$ & 7.11 \\
\hline $\mathrm{Ca}(\mathrm{OH})_{2}$ & 3.11 \\
\hline $\mathrm{Fe}_{2} \mathrm{O}_{3}$ & 36.7 \\
\hline $\mathrm{MnO}_{3}$ & 3.46 \\
\hline $\mathrm{NaOH}$ & 15.3 \\
\hline $\mathrm{SiO}_{2}$ & 7.51 \\
\hline $\mathrm{UO}_{2}$ & 2.04 \\
\hline other & 2.00 \\
\hline total & 77.2 \\
\hline
\end{tabular}

Table 6: Summary of Uranium Content of the Tank 43H sample (values in parentheses are standard deviations of two measurements)

\begin{tabular}{|c|c|c|c|}
\hline Tank 43H & $\begin{array}{c}\text { Uranium } \\
\text { Concentration } \\
\text { (wt \%) }\end{array}$ & $\begin{array}{c}\text { Portion of Total } \\
\text { Uranium in } \\
\text { Slurry (wt\%) }\end{array}$ & $\begin{array}{c}{ }^{235} \text { U Enrichment } \\
\text { (\%) }\end{array}$ \\
\hline Decanted Supernate & 0.0010 & 0.05 & $0.56(0.02)$ \\
\hline Wash Solution & 0.0006 & 0.03 & $0.58(0.11)$ \\
\hline Insoluble Solids & $1.86(0.06)$ & 99.92 & $0.52(0.01)$ \\
\hline
\end{tabular}

\section{Microscopy and Spectroscopy}

Originally, solids were isolated by filtration and analyzed by XRD and SEM. The preparation for these analyses did not include washing of the solids to remove components in the remaining interstitial supernate. Thus, some components observed in this analysis (sodium nitrate and sodium nitrite) were likely contributed by the interstitial supernate and were not likely part of the original sample solids.

Figure 2 shows the XRD spectra for the unwashed Tank 43H solids. The major components of the crystals identified are the residual salts sodium nitrate, sodium nitrite, and sodium carbonate. The other phases noted include cancrinite (sodium aluminsilicate), clarkeite (uranium oxy-hydroxide), magnetite (iron oxide), and quartz (silicon oxide). Additionally, the noisy and elevated baseline of the spectra obtained suggests that the solids contained additional amorphous materials, which cannot be characterized by XRD. 


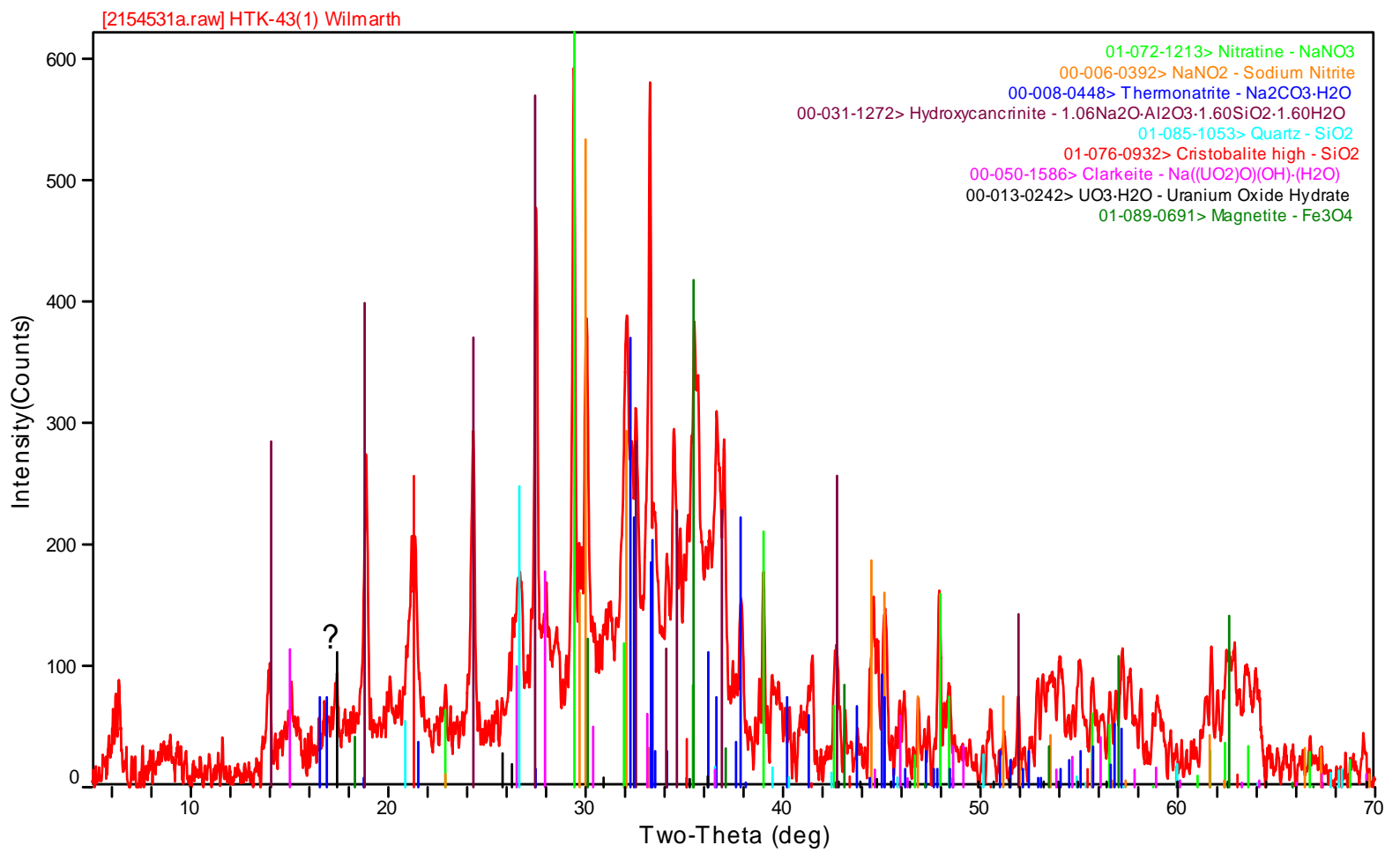

Figure 2: XRD for the unwashed Tank $43 H$ solids 


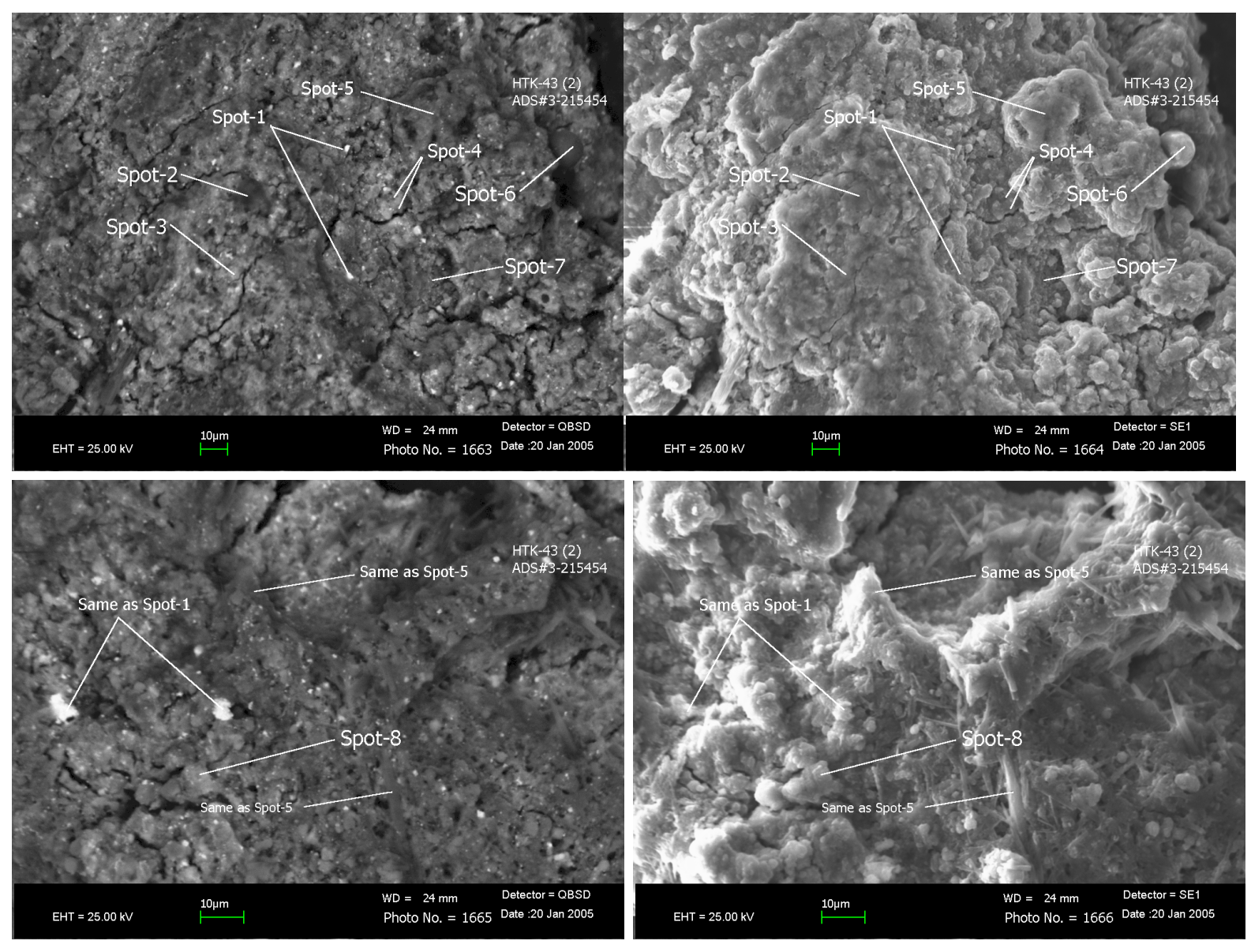

Figure 3: SEM micrographs of two areas of the unwashed prepared Tank 43H solids. The top two images are Area 1 and the bottom two images are Area 2. Images on the left are backscattered electron and images on the right are secondary electron images. 

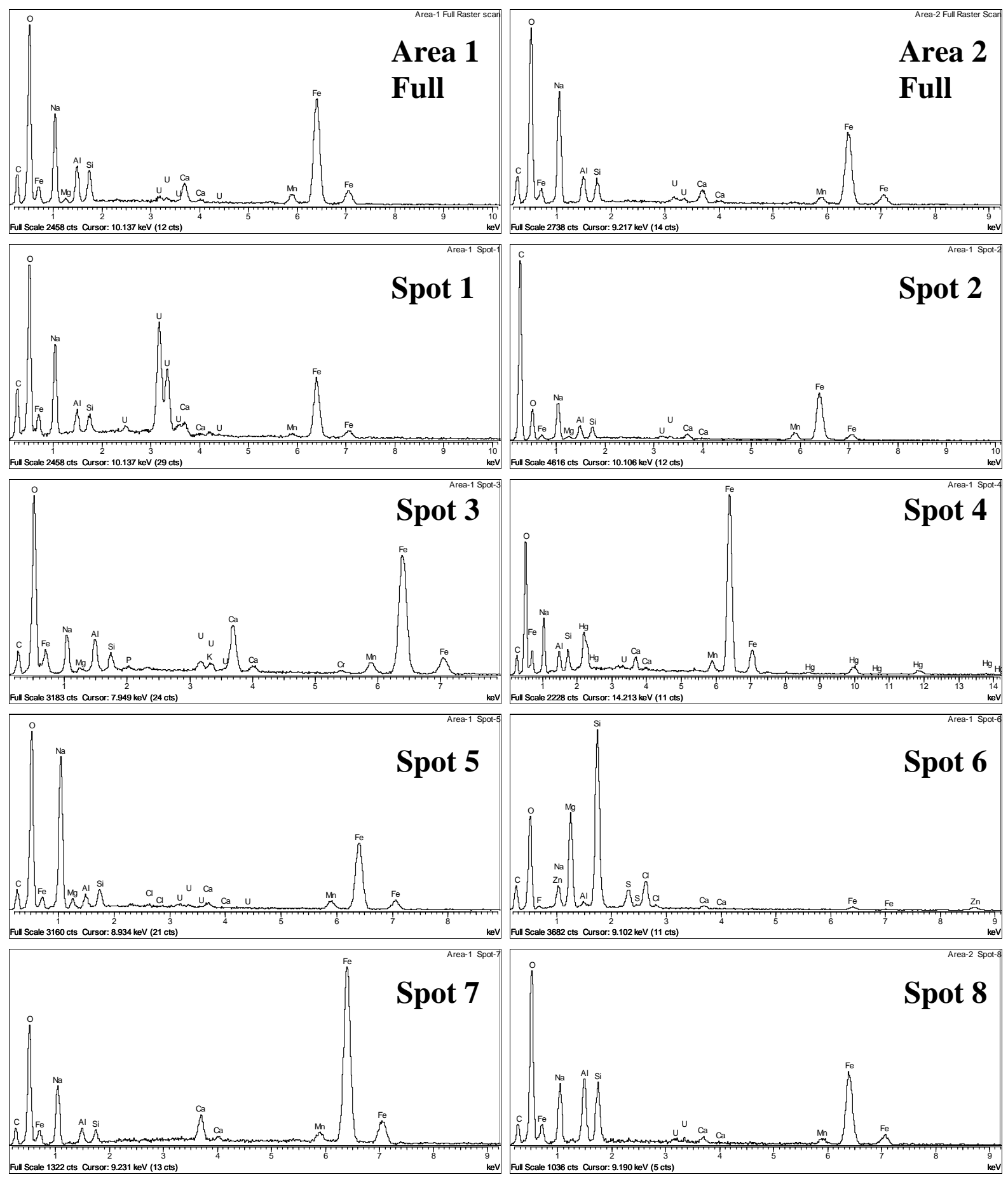

Figure 4: EDS spectra corresponding to Figure 3 
Figure 3 and Figure 4 contain the SEM photos and the corresponding XEDS spectra for the Tank $43 \mathrm{H}$ solids. General area raster scans showed a strong response for oxygen, sodium, and iron; a moderate response for aluminum, silicon, and carbon, and a smaller response for calcium, magnesium, and uranium. While the results from these large-area scans of two different portions of the sample insoluble solids agreed well with each other, spot scans showed the concentrations of some materials to be highly localized. Many of the more focused scans of particles revealed this sample to contain localized regions rich in either uranium, iron, or mercury. Typically, the silicon and aluminum peaks were approximately the same size. One area of the solids (Spot 6) was substantially different from the other locations investigated. This spot had a large peak for silicon with a very small peak for aluminum. Other components at that location were magnesium and oxygen, with smaller response for sulfur, chlorine, carbon, and zinc.

\section{$\underline{\text { Solids Settling Test }}$}

SRNL investigated the settling behavior of the solids in the as-received Tank 43H sample. We performed a simple test in which $5.1 \mathrm{~mL}$ of slurry was introduced to each of two $10 \mathrm{~mL}$ graduated cylinders. The overall height of this $5.1 \mathrm{~mL}$ slurry was 2.5 inches. The cylinders were capped, left undisturbed, and observed periodically. Over the first three days of settling, the rate of decent of the settled zone interface was approximately 1/8-inch per day. After this period, further compaction was observed at a slower rate.

The cylinders used in this test are shown in Figure 5, where insert $a$ is on the initial day of testing and insert $b$ is on the $15^{\text {th }}$ day of testing. Settling appeared to be in the zone-settling and compaction regimes, where a distinct interface is evident between the clarified supernate and the compacted solids (see insert $b$ in Figure 5). As seen in Figure 6, the solids settled to about $70 \%$ of their original volume within two weeks, and additional settling from two to eight weeks was insignificant. This is in contrast with centrifuging $10.4 \mathrm{~mL}$ of as received sample (insert $c$ in Figure 5 and dashed line in Figure 6), where the solids were compacted into only about $22 \%$ of the overall volume. 

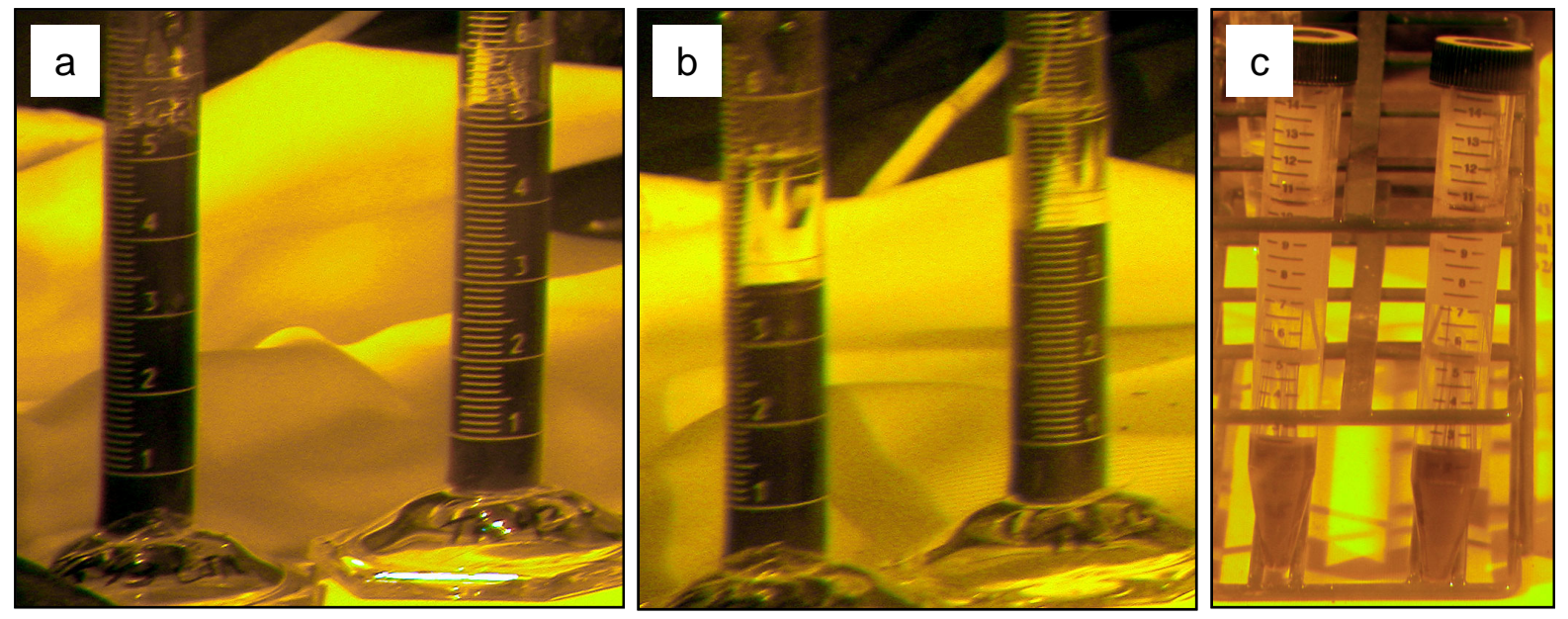

Figure 5: Solids settling tests of the Tank $43 \mathrm{H}$ sample, performed in duplicate: a) day 0 of settling $5.1 \mathrm{~mL}$, b) day 15 of settling $5.1 \mathrm{~mL}, \mathrm{c}$ ) centrifuging $10.4 \mathrm{~mL}$.

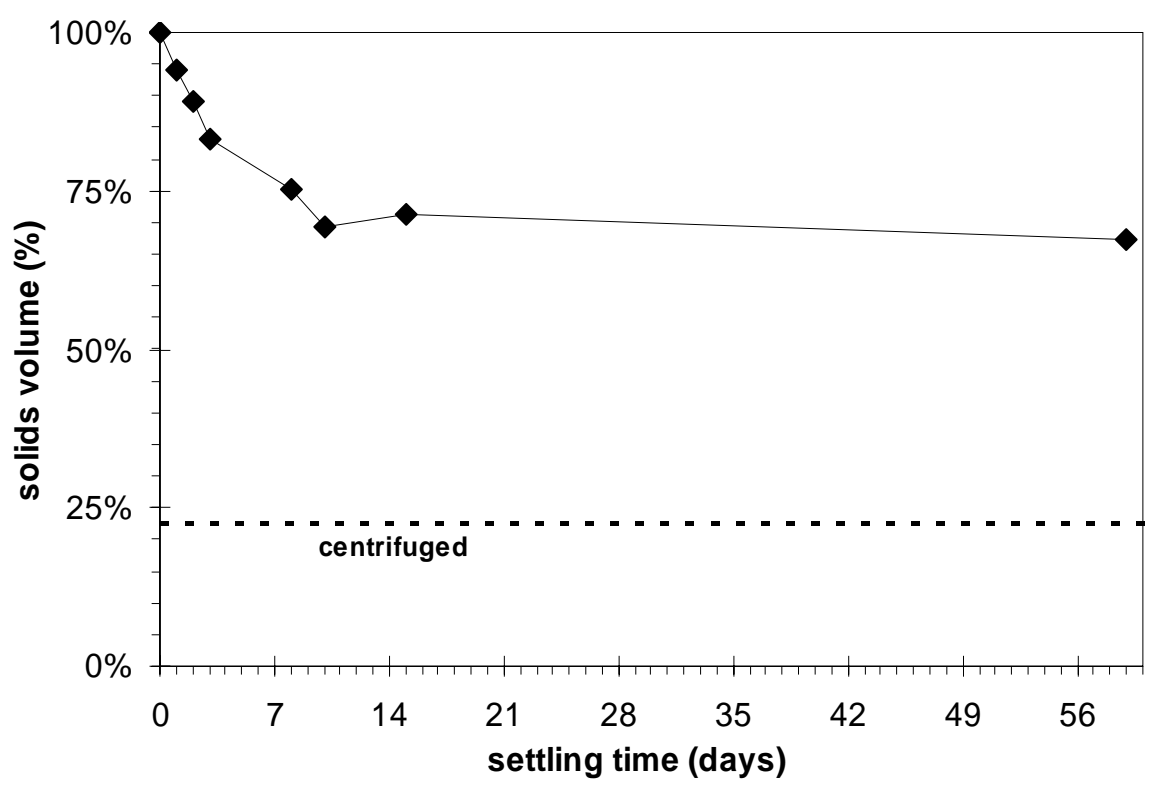

Figure 6: Percent of volume below the supernate/sludge interface for settling $5.1 \mathrm{~mL}$ samples for eight weeks, as compared with centrifuging $10.4 \mathrm{~mL}$ samples.

\section{Sludge Level Turbidity Meter Testing}

The turbidity of suspensions in a fluid media is typically measured by passing a light through a suspension and observing the light scattered $90^{\circ}$ from the incident light. As more light is scattered by suspended solids, more light would be detected by the sensor observing $90^{\circ}$ scattered light. If the solids loading of the slurry is increased to a level that scattered light is subsequently blocked or absorbed and does not reach the detector, the light reaching the 
detector would start to decrease. Thus, the $90^{\circ}$ scattering turbidity measurement might give similar low detected light results for very clear liquids and very concentrated slurries. Therefore, a typical turbidity meter might not provide the best results for detecting the level of interface between clear supernate and concentrated slurry. A standard turbidity meter is, however, appropriate for testing dilute slurries of sludge. Figure 7 contains turbidity results of dilute sludge and monosodium titanate slurries adapted from a previous report. ${ }^{5}$ The turbidity measured with the $90^{\circ}$-scattered-light meter begins to plateau above sludge solids of $0.01 \mathrm{wt} \%$.

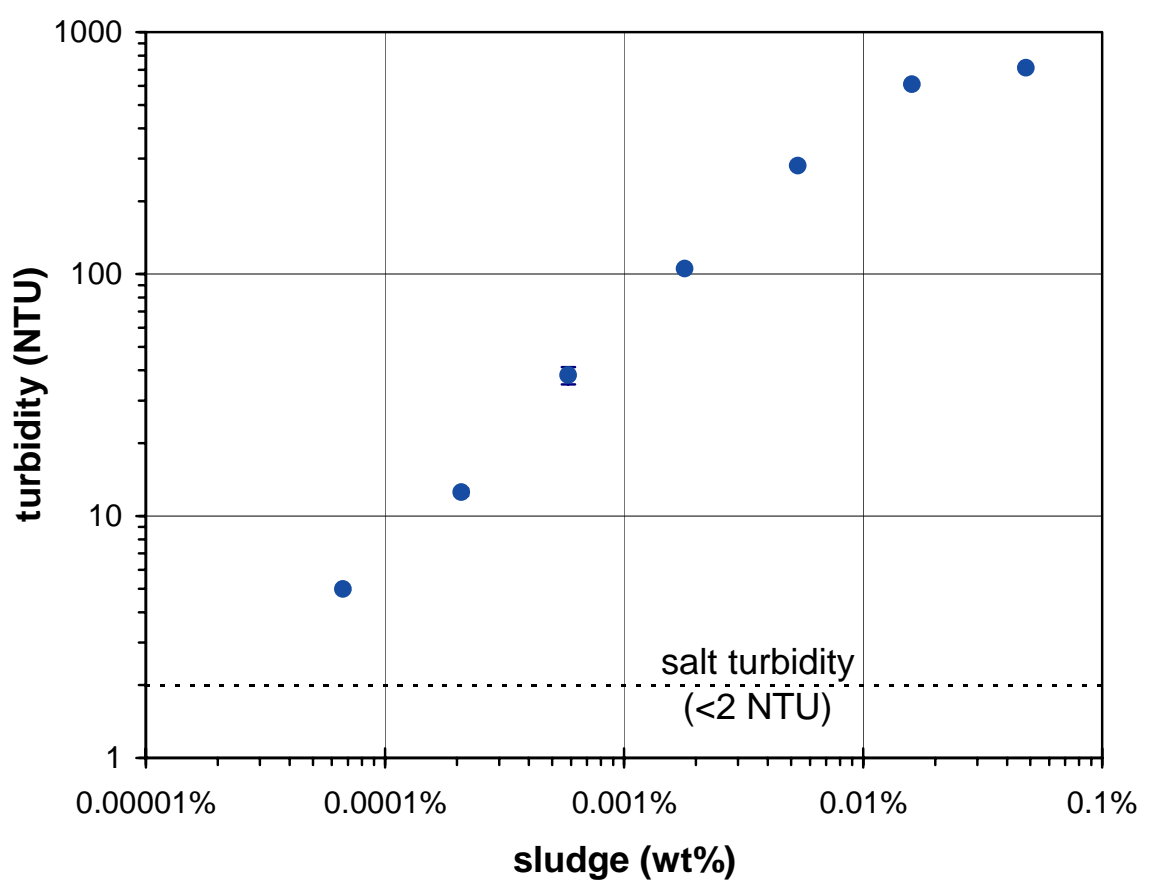

\section{Figure 7: Turbidity of dilute sludge simulants measured with a water-quality turbidity meter.}

The Sludge Level Turbidity Meter, however, has a different design than the typical turbidity meter. The detector is pointed toward the incident light, and the detector measures light transmitted through the slurry rather than that scattered by the slurry. The sludge level turbidity meter that is used by the HLW tank farms at SRS observes transmitted light. This type of meter is not a true turbidity meter, as mechanisms other than scattering (such as absorption by the liquid or particles) may contribute to the response. ${ }^{6}$

Previous studies of the behavior of an earlier incarnation of the Sludge Level Turbidity Meter, then called the ESP Turbidity Meter, were preformed in the TNX Sludge Receipt Tank. ${ }^{7}$ The meter adequately determined the level of a sharp interface between settled sludge and clarified supernate, but testing did not include moderately turbid dilute suspensions of sludge. 
For this testing, SRNL made turbid solutions of simulated HLW sludge. The specific lot of sludge used in these preparations was prepared at Clemson University in support of Sludge Batch 2. First, as much supernate as possible was removed from the sludge. Next, water was added to the SB2 sludge to dilute the interstitial liquid. The sludge was drained, dried, and re-suspended in varying amounts water. Soluble solids in the final sludge slurries contributed only about $0.1 \%$ relative to the total solids. A series of two-liter test solutions were prepared with the following insoluble sludge solids levels: $0.008 \mathrm{wt} \%, 0.04 \mathrm{wt} \%, 0.09$ wt $\%, 0.2 \mathrm{wt} \%, 0.4 \mathrm{wt} \%$, and $1 \mathrm{wt} \%$. Most of these test solutions have suspended sludge solids at levels greater than those practical for determining turbidity by $90^{\circ}$ scattering. With a standard turbidity meter, the $0.008 \mathrm{wt} \%$ solution read $145 \mathrm{NTU}$ and the $0.04 \mathrm{wt} \%$ solution read 422 NTU. Figure 9 is a photograph of $30 \mathrm{~mL}$ aliquots of the test solution lighted from behind.

The Tank Farm Sludge Level Turbidity Meter is composed of a tape measure and cable that lowers the detector head into a HLW tank. As seen in Figure 8, the detection head of the meter is a single-use item made of low cost materials. One leg of the meter is a flashlight bulb inside of a centrifuge tube cabled to a $6 \mathrm{~V}$ battery on the tanktop. The other leg is a PerkenElmer photocell model VT23N1 (inside a centrifuge tube and pointed in the general detection of the bulb) that is connected to an ohm-meter at the tanktop. The unit tested had an original gap between the two legs of 2-1/8 inches.

Bench-scale testing of the Sludge Level Turbidity Meter at SRNL involved taking resistance readings of the stirred $2 \mathrm{~L}$ test solutions inside of a test beaker. The test beaker was a $4 \mathrm{~L}$ stainless steel beaker with the inside surfaces painted flat black to reduce reflection. The beaker was covered with an opaque black lid to eliminate the influence of ambient light. The solutions were mixed to a vortex to assure constant solids content. The light source was activated and the meter head, as seen in Figure 8, was lowered into the testing apparatus. Readings were recorded with the meter head situated at several locations in the beaker. The resistance of the photocell was monitored using a Fluke model 8060A multimeter.

In general, two categories of responses were obtained from the Sludge Level Turbidity Meter. For the more dilute slurries, the resistance reading would rise to a constant value within the first five seconds that the meter was placed in solution. For this response, the constant value obtained was recorded, and the meter was moved to different locations in the test solution for comparison. For the more concentrated slurries, very little light reached the detector after it was lowered into the solution and the resistance rose continuously.

The results from this testing are shown in Table 7. The unit was reconfigured for a gap of one inch between the light tube and the detector tube and additional readings were obtained. The ranges reported are variations with location in the testing beaker and between repeated tests. Data that are not reported as time dependent had essentially reached constant values within five seconds, and data reported as time dependant continued to increase even after the five minute period of data recording. Figure 10 and Figure 11 contain graphical representations of the data.

The original detector gave readings that continued to increase with time for the slurries of 0.2 wt\% solids and greater. Due to the lack of light reaching the detector, this system was not 
able to differentiate between slurries of $0.4 \mathrm{wt} \%$ solids and greater. This unit did, however, clearly respond to solids well below the Tank Farm level of interest for transfers of $1 \mathrm{wt} \%$. As expected, reducing the gap between the light source and the detector influenced the readings of concentrated slurries. Since reducing the gap allowed more light to reach the detector, the system was able to differentiate between more concentrated slurries.

The trends noted here should hold for actual-waste sludge slurries, but the exact meter readings are likely a function of particle size. The solutions tested represented smaller sludge particles as could be suspended in actual-waste. Because only one Sludge Level Turbidity Meter unit was used in these tests, we can not precisely extend these results directly to other units due to the uncertainty of variation between different units.

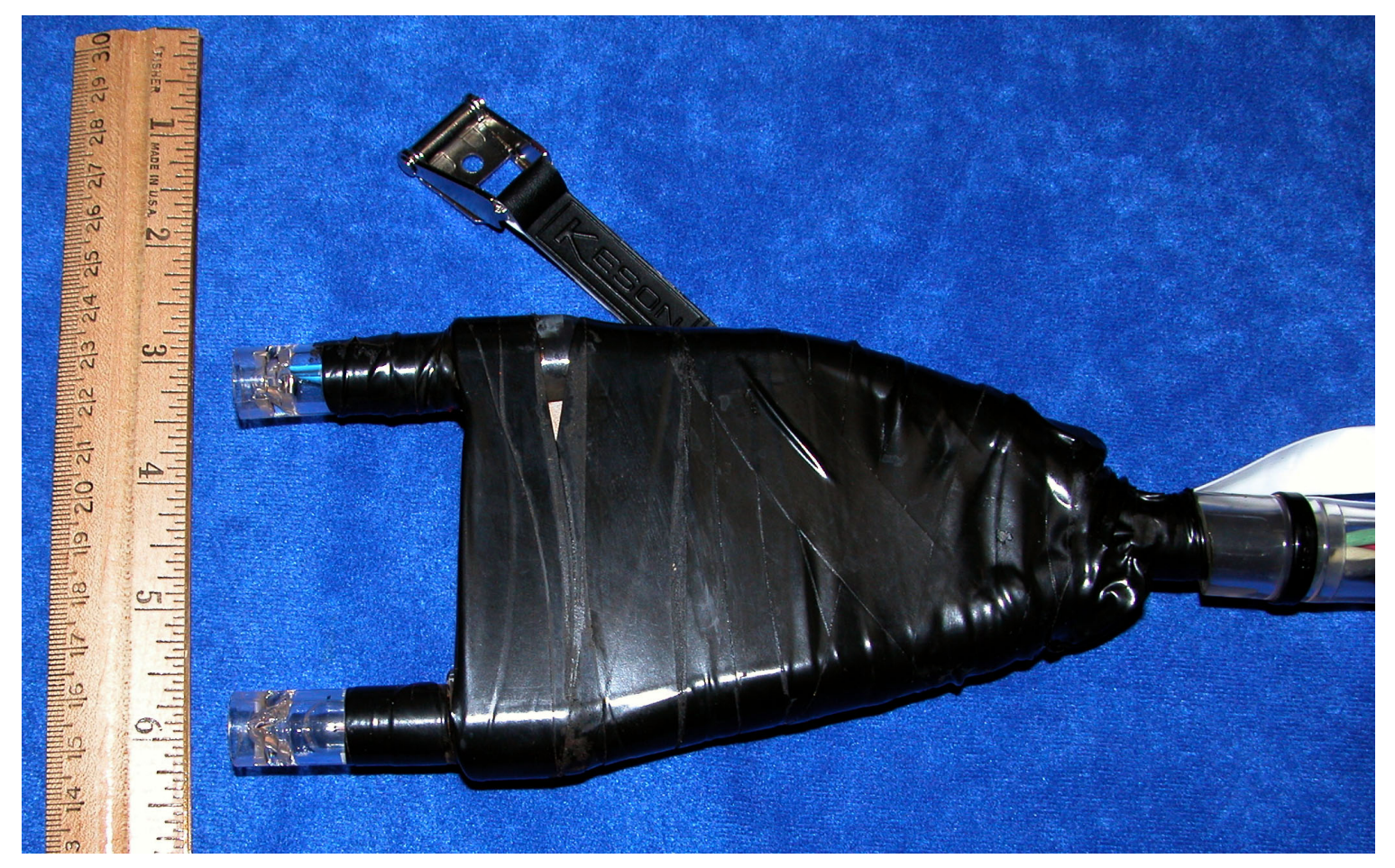

Figure 8: Photograph of the head of the Sludge Level Turbidity Meter system.

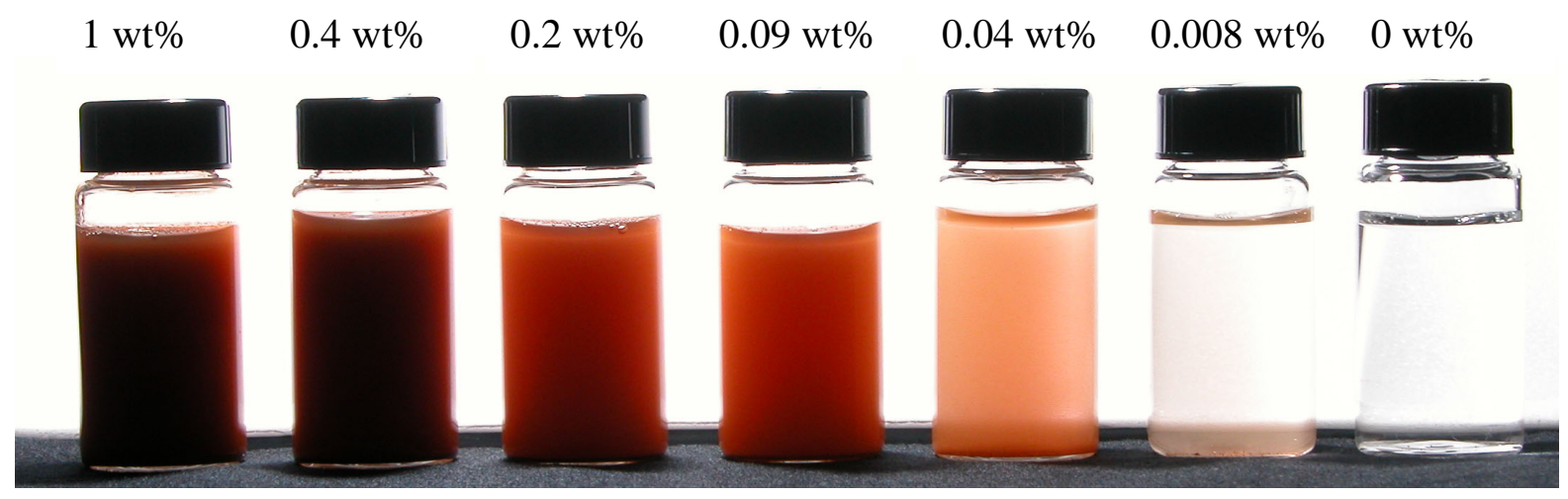

Figure 9: Transmitted light through $30 \mathrm{~mL}$ aliquots of simulated sludge. 
Table 7: Summary of resistance readings during Sludge Level Turbidity Meter testing.

\begin{tabular}{|c|c|c|}
\hline Material & $\begin{array}{c}\text { Original (2.13-inch) Gap } \\
\text { (k-ohm) }\end{array}$ & $\begin{array}{c}\text { Narrow (1-inch) Gap } \\
\text { (k-ohm) }\end{array}$ \\
\hline air & $8.7-9.2$ & -- \\
\hline water & $9.6-10.7$ & -- \\
\hline 0.008 wt $\%$ solids & $14.4-15.1$ & -- \\
\hline $0.04 \mathrm{wt} \%$ solids & $41-47$ & -- \\
\hline 0.09 wt $\%$ solids & $300-400$ & -- \\
\hline \multirow{3}{*}{$0.2 \mathrm{wt} \%$ solids } & $830 @ 10$ s. & \multirow{3}{*}{530} \\
\hline & 890 - $1000 @ 20$ s. & \\
\hline & $980 @ 120$ s. & \\
\hline \multirow{3}{*}{$0.4 \mathrm{wt} \%$ solids } & $4000 @ 10$ s. & $1700 @ 5$ s. \\
\hline & $7500 @ 20$ s. & $2400 @ 20$ s. \\
\hline & $39000 @ 120$ s. & $3000 @ 120$ s. \\
\hline \multirow{3}{*}{1.0 wt $\%$ solids } & $4300 @ 10$ s. & $2600 @ 5$ s. \\
\hline & $7700 @ 20$ s. & $10000 @ 20$ s. \\
\hline & 40000@120s. & 50000@120s. \\
\hline
\end{tabular}

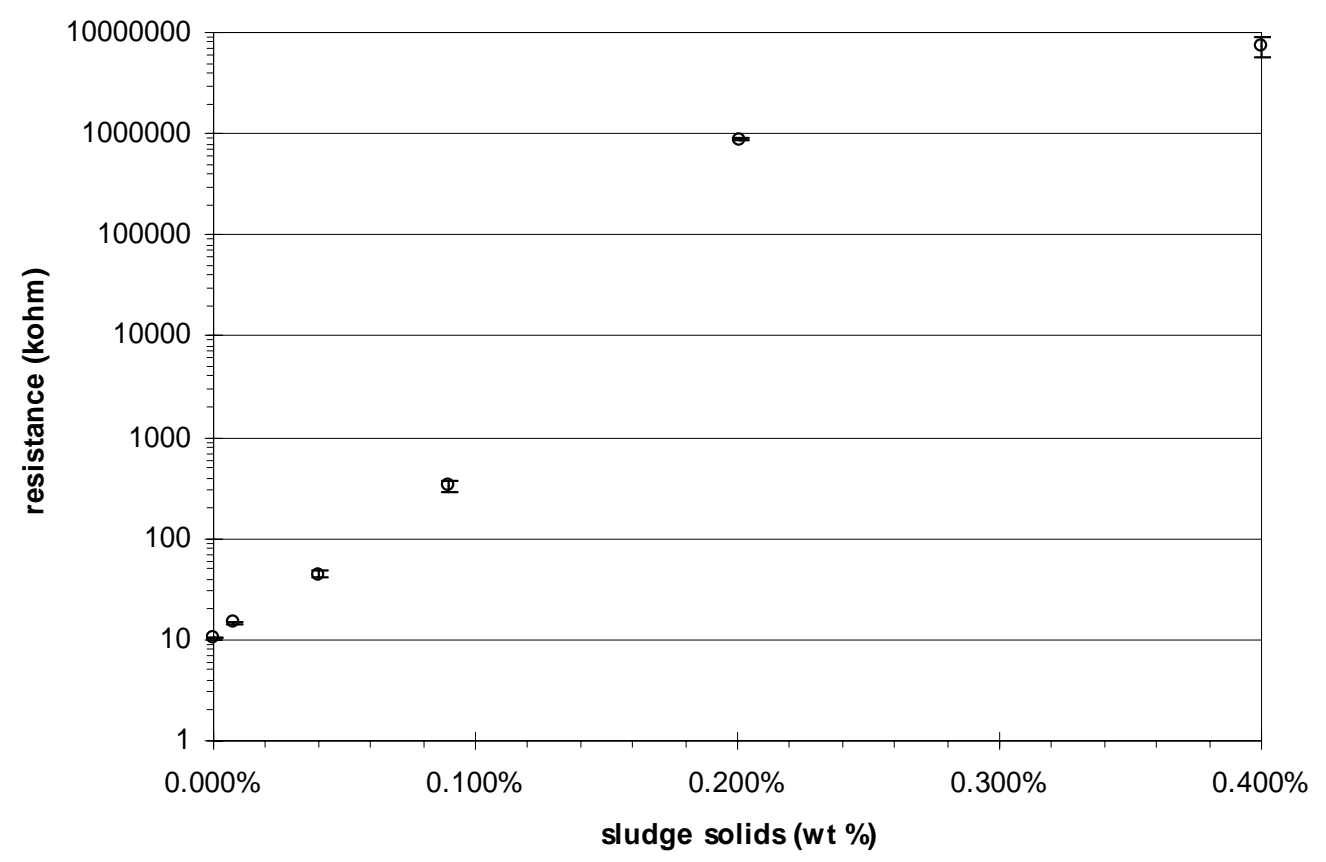

Figure 10: Resistance readings for the Sludge Level Turbidly Meter (with original 21/8" gap) with various levels of simulated sludge solids. Values reported for 0.2 and 0.4 wt \% slurries read at 20 sec. 1 wt \% slurry matched 0.4 wt \% slurry results. 


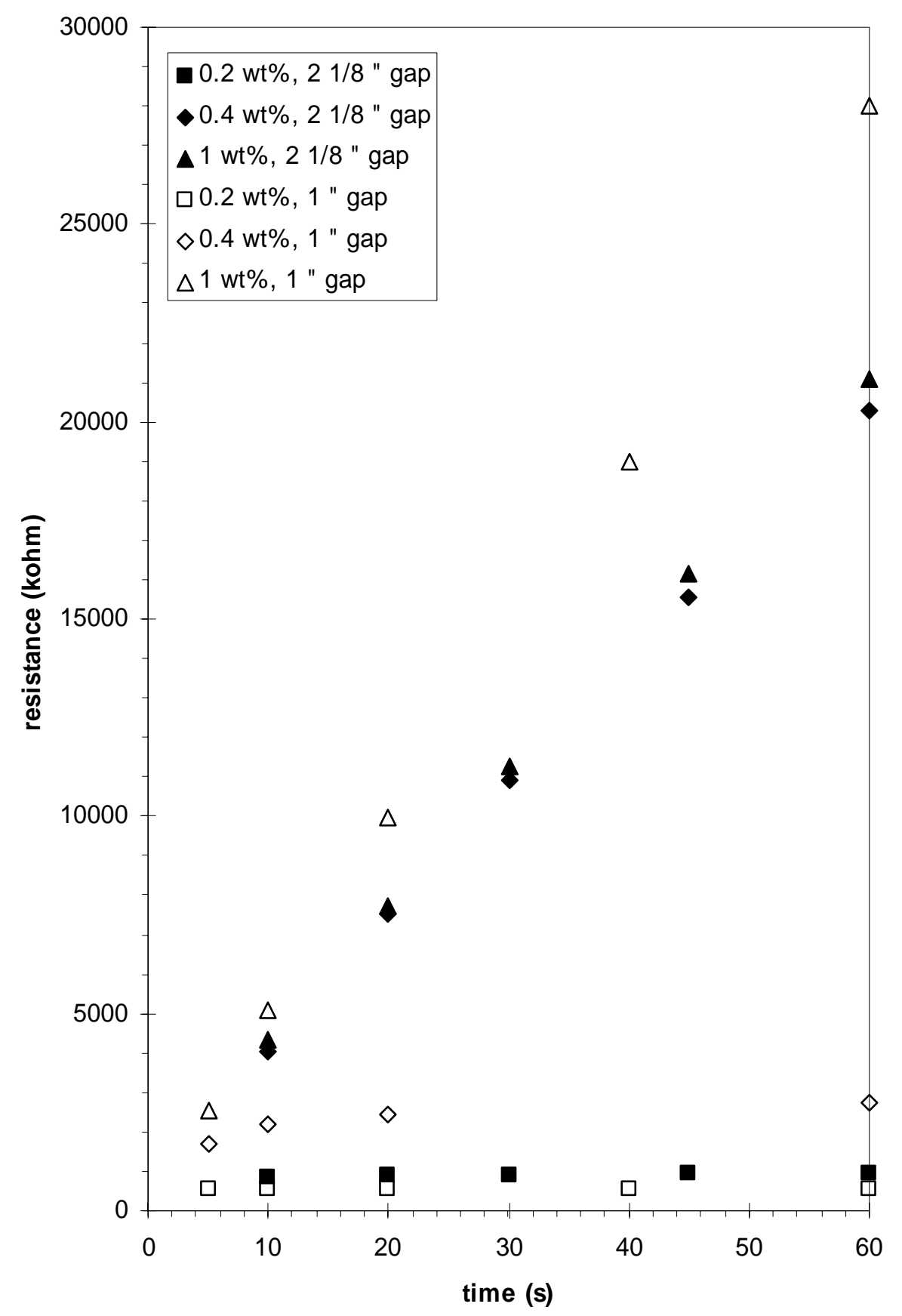

Figure 11: Time-dependent behavior of turbidity meter readings with two different gap sizes (2-1/8" and 1 ") when used with concentrated sludge slurries 
WSRC-TR-2005-00161

Revision 0

\section{Quality Assurance}

This work was performed in response to the CBU task technical request. ${ }^{8}$ Laboratory Notebook WSRC-NB-2003-00197, WSRC-NB-2003-00088, and various ADS notebooks contain the experimental data.

\section{Acknowledgements}

The authors thank the following for their important contributions to this project: Dee Wheeler, Jeannine Mills, Cecil May, Dennis Lewis, Vicki Dukes, Henry Bolton, Michael Summer, David Missimer, Michael Whittaker, William Boyce, June Hart, David DiPrete, Ceci DiPrete, and Leigh Brown.

\section{References}

${ }^{1}$ P. D. d'Entremont and D. T. Hobbs, "Migration of Uranium from Tank 43H Sludge,” WSRC-TR-2001-00127, Rev. 0, March 29, 2001.

${ }^{2}$ P. D. d'Entremont and J. M. Gillam, "Results of Tank 43H Samples for Uranium-235 Enrichment,” WSRC-TR-2001-00470, Rev. 0, October, 2, 2001.

3 J. M. Gillam and P. D. d’Entremont, "Enrichment Control Program for 2H Evaporator," WSRC-RP-2001-00575, Rev. 1, July 10, 2001.

${ }^{4}$ SRS Analytical Laboratories Customer Sample Report, Sample ID 200377750, January 26, 2005.

${ }^{5}$ C. J. Martino, M. R. Poirier, F. F. Fondeur, and S. D.Fink, "Flocculating, Settling and Decanting for the Removal of Monosodium Titanate and Simulated High-Level Waste Sludge form Simulates Salt Supernate,” WSRC-TR-2001-00413, October 16, 2001.

${ }^{6}$ D. Soleta, “Optical Concentration Transducers,” in Process/Industrial Instruments and Controls Handbook, $5^{\text {th }}$ ed., pg 6.55 to 6.70 , (1999).

${ }^{7}$ L. L. Kilpatrick, "Evaluation of ESP Turbidity Meter for Measuring Waste Tank Sludge Level,”WSRC-RP-93-656, May 11, 1993.

${ }^{8}$ J. Russell, “Task Technical Request: Tank 43 Sample Solids Analysis,” HLE-TTR-2005040, January 2005. 